OPEN ACCESS

Edited by:

Emira Ayroldi,

University of Perugia, Italy

Reviewed by:

Veronique Godot,

INSERM U955 Institut Mondor de

Recherche Biomédicale

(IMRB), France

Vivaswath Ayyar,

University at Buffalo, United States

*Correspondence:

Jacqueline K. Flynn

jacqueline.flynn@monash.edu

Eric F. Morand

eric.morand@monash.edu

Specialty section:

This article was submitted to Autoimmune and Autoinflammatory Disorders,

a section of the journal

Frontiers in Immunology

Received: 25 April 2019 Accepted: 04 July 2019

Published: 17 July 2019

Citation:

Flynn JK, Dankers W and Morand EF (2019) Could GlLZ Be the Answer to

Glucocorticoid Toxicity in Lupus? Front. Immunol. 10:1684.

doi: 10.3389/fimmu.2019.01684

\section{Could GILZ Be the Answer to Glucocorticoid Toxicity in Lupus?}

\author{
Jacqueline K. Flynn*, Wendy Dankers and Eric F. Morand* \\ School of Clinical Sciences at Monash Health, Monash University, Melbourne, VIC, Australia
}

Glucocorticoids (GC) are used globally to treat autoimmune and inflammatory disorders. Their anti-inflammatory actions are mainly mediated via binding to the glucocorticoid receptor (GR), creating a GC/GR complex, which acts in both the cytoplasm and nucleus to regulate the transcription of a host of target genes. As a result, signaling pathways such as NF-кB and AP-1 are inhibited, and cell activation, differentiation and survival and cytokine and chemokine production are suppressed. However, the gene regulation by GC can also cause severe side effects in patients. Systemic lupus erythematosus (SLE or lupus) is a multisystem autoimmune disease, characterized by a poorly regulated immune response leading to chronic inflammation and dysfunction of multiple organs, for which GC is the major current therapy. Long-term GC use, however, can cause debilitating adverse consequences for patients including diabetes, cardiovascular disease and osteoporosis and contributes to irreversible organ damage. To date, there is no alternative treatment which can replicate the rapid effects of GC across multiple immune cell functions, effecting disease control during disease flares. Research efforts have focused on finding alternatives to GC, which display similar immunoregulatory actions, without the devastating adverse metabolic effects. One potential candidate is the glucocorticoid-induced leucine zipper (GILZ). GILZ is induced by low concentrations of GC and is shown to mimic the action of GC in several inflammatory processes, reducing immunity and inflammation in in vitro and in vivo studies. Additionally, GILZ has, similar to the GC-GR complex, the ability to bind to both $\mathrm{NF}-\kappa \mathrm{B}$ and $\mathrm{AP}-1$ as well as DNA directly, to regulate immune cell function, while potentially lacking the GC-related side effects. Importantly, in SLE patients GILZ is under-expressed and correlates negatively with disease activity, suggesting an important regulatory role of GILZ in SLE. Here we provide an overview of the actions and use of GC in lupus, and discuss whether the regulatory mechanisms of GILZ could lead to the development of a novel therapeutic for lupus. Increased understanding of the mechanisms of action of GILZ, and its ability to regulate immune events leading to lupus disease activity has important clinical implications for the development of safer anti-inflammatory therapies.

Keywords: GILZ, glucorticoids, lupus (SLE), transcription factor, treatment, regulation 


\section{SYSTEMIC LUPUS ERYTHEMATOSUS (SLE)-A DIVERSE CHRONIC AUTOIMMUNE DISEASE}

Systemic lupus erythematosus (SLE) is an incurable chronic disease, affecting $\sim 1$ in 1,000 people world-wide $(1,2)$, resulting in a marked loss of life expectancy and quality of life. The prevalence of SLE is higher in women, particularly of child bearing age, and in African American, Asian and indigenous Australian populations (1). SLE is one of the top 10 causes of death in young adult women (3), but the current treatment consists mainly of glucocorticoids (GC) which cause severe adverse effects (4).

SLE is characterized by multisystemic inflammation occurring in periodic disease flares, which can affect multiple organs such as the kidneys, lungs, brain, heart, blood, and skin. The most common symptoms include rash, arthritis, and fatigue. The heterogeneity of the disease makes clinical diagnosis and measurement very challenging, resulting in the use of clinical criteria to categorize patients with autoimmune disease as having SLE. For example, the American College of Rheumatology (ACR) classification criteria, which comprise 11 disease features, identifies patients who have at least four features as SLE (5). The requirement for multiple features highlights the heterogeneity of the disease. The majority of SLE patients are positive for antinuclear antibodies (ANA) which target the nuclear components of cells. The most commonly detected specific autoantibodies are dsDNA, anti-Ro and anti-Sm antibodies which also can act as markers for kidney disease (6). Furthermore, the presence of autoantibodies especially to Ro, La, $\mathrm{Sm}$, and RNP is strongly associated with detection of interferon (IFN)-induced gene expression in peripheral blood (7). This profile of IFN-induced genes is termed the IFN signature, and is found in approximately $95 \%$ of children and $50-70 \%$ of adults with SLE (8-10).

Although the initiating cause of SLE is unknown, it is thought to result from a failure in tolerance checkpoints in several components of the immune system. This includes the escape and proliferation of autoreactive B cells, the development of autoantibodies, and the formation of immune complexes which can initiate organ inflammation and/or directly damage cells $(8,11)$.

\section{Production of Autoantibodies and Immune Cell Dysfunction}

One theory regarding the initiation of SLE is impaired clearance of apoptotic cells. Phagocytes from SLE patients are less effective in clearing apoptotic cells, and the uncleared apoptotic cells present apoptotic bodies and nucleic antigens to the extracellular space (12). These nucleic antigens, if internalized via Fc receptor binding of nucleic acid immune complexes, activate toll like receptors (TLRs). Particularly TLR 7 whose ligand is ssRNA [associated with the production of anti-Sm antibodies in SLE (13)], and TLR 9 whose ligand is unmethylated CpG-rich DNA. Downstream signaling resulting in the production of multiple cytokines, including interleukin (IL)-6, IL-1, and tumor necrosis factor (TNF)- $\alpha$, which play a pivotal role in immune cell dysfunction and chronic inflammation (14).

Importantly, this pathway also leads to production of type I IFN (IFN- $\alpha$ and IFN- $\beta$ ), an important hallmark of SLE (15). Type I IFNs can also be induced via TLR-independent pathways such as retinoic acid-inducible gene 1 (RIG-I), melanoma differentiation-associated protein 5 (MDA-5) and cyclic GMPAMP synthase (cGAS) receptors which activate innate immune cells through the detection of cytoplasmic nucleic acids (16). The main producers of type I IFN are plasmacytoid DCs (pDC). Despite a reduction in the number of circulating pDC in SLE patients, these cells accumulate at inflamed sites, particularly the skin and kidneys, and secrete large amounts of type I IFNs $(17,18)$.

One of the actions of IFN- $\alpha$ is to prime mature neutrophils and assist the formation of neutrophil extracellular traps (NETs) $(19,20)$. NETs are mesh-like structures composed of chromatin fibers and nuclear components, designed to trap and kill microbes (21). However, when inappropriately cleared, these NETs are also a source of auto-antigens. Thereby, they contribute to the development of auto-antibodies, particularly against dsDNA, and the immune complexes that cause organ damage in SLE (22). Finally, by exposing intracellular nucleic acid antigens, NETs activate pDCs and further exacerbate the production of type I IFN, creating a cycle of type I IFN production and NET formation in SLE patients (20).

Components of apoptotic cells can also be taken up by antigen-presenting cells and will activate $\mathrm{T}$ and $\mathrm{B}$ cells through the normal antigen presentation pathway. $\mathrm{CD} 4^{+} \mathrm{T}$ cells from SLE patients display a high expression of CD40 ligand (CD40L) compared to healthy donors, which also assists in activation and differentiation of $B$ cells due to its role as co-stimulatory molecule (23). T follicular helper cells are expanded in SLE patients and promote the differentiation of autoantibody producing $\mathrm{B}$ cells (24). Additionally, Th17 cells, which promote inflammation, are increased in SLE, whilst $\mathrm{T}$ regulatory cells (Tregs) are suppressed (25). Furthermore, increased T cell numbers in SLE provides more $\mathrm{T}$ cell help for $\mathrm{B}$ cell differentiation, survival and proliferation (25), as does an elevated level of B cell activating factor (BAFF; also known as B Lymphocyte Stimulator, BLyS or TNF like ligand, TNFSF13B). Overexpression of BAFF is associated with increased survival of activated autoreactive B cells and a decrease in self-tolerance which leads to lupus-like autoimmune disease in mouse models (26). BAFF also assists in B cell survival during differentiation and is associated with SLE disease activity (14). B cells, which are activated by $\mathrm{CD} 4^{+}$ $\mathrm{T}$ cells, contribute to disease both via antibody production and antigen presentation to T cells. B cells in SLE are hyperactive and contribute significantly to the production of autoantibodies, cytokines and augmented antigen presentation to $\mathrm{T}$ cells (25). Naiive B cells are reduced in number in the blood of SLE patients, whilst there is an increase in plasmablasts leading to an increase in antibody production. The cycle of excess antibody production perpetuates inflammation via immune complexes, as noted above.

Thus, SLE is a diverse autoimmune disease mediated by the disordered activation of multiple immune cells causing widespread chronic inflammation, resulting in multi-system 
morbidity and making management an enormous challenge. To combat the diverse nature of the systemic inflammation, the broad effects of GC on immune cell function has led to them being used widely to elicit broad suppression of autoimmunity and its inflammatory consequences.

\section{Glucocorticoid Treatment of SLE}

GC have been used for decades for the treatment of inflammatory and autoimmune diseases such as rheumatoid arthritis and SLE $(27,28)$. GC have a substantial impact on the immune system via the ability to regulate 1,000 of genes. Gene regulation occurs via GC binding to the GC receptor (GR), which is expressed in almost every cell in the body. Thus, the effects of GC are not tissue- or organ-specific and treatment with GC has the ability to target inflammation in multiple parts of the immune system, and in multiple organs, simultaneously. This is valuable in a disease like SLE, in which cell types are implicated and multiple organs are affected. In SLE, dosing of GC varies according to the severity of inflammation and the nature of the organs affected (28). Unfortunately, adverse effects of GC, chiefly metabolic, are also dose-dependent, and are seen almost universally in patients with SLE treated with GC long term $(28,29)$.

To reduce reliance on GC, and hence dose-dependent adverse effects, patients with SLE are usually also treated with additional immunomodulatory or immunosuppressive drugs, such as antimalarials, mycophenolate mofetil, or azathioprine. These drugs are also broad spectrum in their effects, and associated with significant adverse effects. The only targeted therapy approved for the treatment of SLE is belimumab, approved by the FDA for use in 2011. Belimumab is a neutralizing human monoclonal antibody to BAFF, which is elevated in SLE, suggesting that a BAFF inhibitor has the potential to control B cell dysfunction in SLE $(14,26)$. Belimumab has been approved for treatment of patients with active autoantibody positive SLE who have not responded to conventional therapies (30). Belimumab does not induce a rapid clinical benefit and though its use is associated with reduced GC dosing (31), GC remains the treatment for the majority of SLE patients. Additional targeted therapies directed against key inflammatory cytokines for SLE, such as IL-6, have been found to be ineffective in Phase II trials in SLE, despite their efficacy in rheumatoid arthritis (32). This suggests upstream targeting of inflammatory signaling pathways is important for development of a GC replacement therapy.

That GC are the mainstay treatment for SLE despite its use being plagued with severe side effects, such as increased cardiovascular disease, osteoporosis and diabetes $(28,29,33)$, highlights the lack of a viable alternative. Thus, there is a critical need for the development of new therapeutics with similar potent immune actions but without the detrimental metabolic effects.

\section{THE MECHANISM OF GC ACTION IN THE TREATMENT OF SLE}

The main mechanism via which GC act on the immune system is through binding to the glucocorticoid receptor (GR). The GR is encoded by the NR3C1 gene and has two major forms,
$\mathrm{GR} \alpha$ and GR $\beta$, which are alternative splicing isoforms from $\mathrm{N} 3 \mathrm{C} 1$ (34). GR $\alpha$ is the form that resides in the cytoplasm and is dependent on GC binding for function. The GR contains an $\mathrm{N}$-terminal regulatory domain, central DNA binding domain, hinge region and C-terminal ligand binding domain (35-37). The GR $\alpha$ is located in the cytoplasm and forms a complex with several proteins including heat shock protein 70 and 90 (38). Upon ligand binding, GR $\alpha$ is released from this complex and can interact with cytoplasmic signal transduction molecules or translocate to the nucleus.

The main mechanisms via which GC drive the transcription and regulation of multiple genes are direct DNA binding, tethering and composite binding (38-40) (Figure 1). In the nucleus, GR $\alpha$ is able to modulate gene transcription through binding to target sequences termed GC-response elements (GREs), largely in the cis-regulatory region of target genes (41). This results in either induction or repression of target gene expression. The binding of the GR $\alpha$ to the GRE can also cause conformational changes in the GR which causes the recruitment of cofactors and coregulators to the site with the ability to modulate and alter the transcriptional rate of many target genes $(35,37)$. Direct DNA binding of the GR $\alpha$ to GREs results in the induction of gene expression and causes the transcription of multiple genes, including anti-inflammatory genes such as IL-10 and IL-1 receptor antagonist $(38,40)$ as well as GC-induced leucine zipper (GILZ). GR $\alpha$ can also directly bind to negative GREs (nGRE), which results in suppression of the transcription of several proinflammatory modulators and cytokines including interleukin (IL)-1 $\beta$ (38, 40, 42). Another form of gene repression, termed tethering, is mediated by the ability of GRs to tether to pro-inflammatory transcription factors such as the p65 subunit of nuclear factor kappa B (NF- $\kappa$ B) and activator protein 1 (AP-1), antagonizing their function $(35,43-$ 45). Finally, composite binding encompasses the binding of GR $\alpha$ to a gene locus containing a GRE as well as a binding site for another transcription factor (Figure 1).

Additional factors also influence the ability of GR $\alpha$ to regulate gene transcription such as chromatin structure, epigenetic regulators, proximity to the TATA box, and indirect activation of target genes $(38,41)$. Next to the genomic actions of $\mathrm{GR} \alpha$, it also affects cellular function through non-genomic mechanisms, including suppression of mitogen activated protein kinases (MAPK) and phosphoinositide 3-kinase (PI3K) signaling pathways and activation of proteins with SRC homology 3 [SH3] domains (46) (Figure 1).

Other factors influencing GC regulation of gene expression include tissue-specific differences in GR expression, and the level of GC dosing $(47,48)$. Whereas, a single bolus GC dose highly activates GC-mediated biological responses, chronic GC dosing can be associated with GC resistance. Studies in acute adrenalectomized rat models have demonstrated that this resistance is correlated with a down-regulation of GR mRNA and cytosolic receptor density $(49,50)$. A study by Ayyar et al. found a similar effect of chronic dosing when studying GILZ as a pharmacodynamic marker of GC action in different rat tissues (47). Similar to Ramakrishnan et al. (50) this study also demonstrated drug-induced tolerance during chronic dosing, 
where GC receptor down-regulation was the main mechanism of regulation (47). Taken together these studies highlight that tissuespecific, and GC-induced, differences in GR levels are important physiological factors to consider in GC responses.

The molecular mechanisms of GR $\alpha$-mediated effects have been extensively studied, however, much less is known about the GR $\beta$ isoform. GR $\beta$ results from alternative splicing in exon 9 of $\mathrm{NR} 3 \mathrm{C} 1$ and is a truncated isoform that lacks helix 11 and 12 from the ligand-binding domain (51). Since these helices are important for ligand binding, GR $\beta$ cannot bind GC and does not directly affect GC-sensitive genes (52). In fact, it is thought that GR $\beta$ acts as a dominant negative regulator for GR $\alpha$. Overexpression of GR $\beta$ suppresses GR $\alpha$-mediated gene transcription, and cells which have higher endogenous levels of GR $\beta$ are less responsive to the effects of GC (53-55). How this inhibition occurs is not well-understood, but various mechanisms have been proposed. These include heterodimerization of GR $\beta$ with GR $\alpha$ to inactivate $\mathrm{GR} \alpha$, competition for binding at GREs and competition for binding to coactivators such as $\operatorname{GRIP1}(53,56,57)$. Furthermore, GR $\beta$ also has transcriptional activity independent of GR $\alpha$ and controls its own set of genes $(58,59)$. Interestingly, GR $\beta$ expression is induced by a variety of pro-inflammatory cytokines, such as IL-2, IL-4, IL-17A, IL-17F, IL-23, and TNF- $\alpha$ (60-62). Given their prominent role in inflammatory diseases and the dominant-negative role of GR $\beta$, it is not surprising that high GR $\beta$ levels seem to be related to GC resistance in diseases such as asthma, ankylosing spondylitis and SLE (63-65). Furthermore, a polymorphism in NR3C1 which enhances the stability of GR $\beta$ is associated with rheumatoid arthritis (66). Therefore, a better understanding of GR $\beta$ biology and how to suppress its function may be an important step toward improving GC-based therapies.

It should be noted that GR $\alpha$ and GR $\beta$ are not the only forms of GR. In fact, 27 splice variants of the NR3C1 gene have currently been identified (67), and hundreds of single nucleotide polymorphisms (SNPs), insertions and deletions which potentially also lead to different variants of the GR proteins have been cataloged (67). Although the physiological role of these variants is currently unknown, they may play a role in individual GC response and therefore warrant further study.

In the context of SLE, GC elicit rapid and potent antiinflammatory effects upon multiple organs and immune cells. Many of the immune regulatory effects of GC are through direct binding to transcription factors including NF- $\kappa \mathrm{B}, \mathrm{AP}-1$, nuclear factor of activated $\mathrm{T}$ cells (NFAT) and T-bet $(38,68,69)$. This causes a myriad of effects upon immune cells, described in more detail below, and important for the treatment of SLE, the suppression of key mediators of inflammation TNF- $\alpha$ and type I IFNs $(9,14,70)$.

\section{Effect of GC Treatment on Immune Cells Operative in SLE}

Thymocytes, particularly double positive $\mathrm{CD}^{+} \mathrm{CD}^{+} \mathrm{TCR}^{\text {low }}$ thymocytes, are sensitive to GC-induced apoptosis (71). Cell death can also be induced in mature $\mathrm{T}$ cells indirectly by GCmediated inhibition of IL-2 activation and production $(72,73)$. GC have been described to affect T cell polarization, shifting the phenotype from Th1 to Th2 $(74,75)$, however it should be noted that GC affect both T-bet and GATA-3 transcriptional activity, with long-term GC treatment favoring Th2 expansion (75). Further support for polarization toward a Th2 phenotype comes from GC increasing expression of Itk, a Tec kinase able to induce Th2 differentiation through the negative regulation of T-bet $(76,77)$. GC also increases Treg number and activity, promoting IL-10 producing $\mathrm{T}$ cells. This is through several mechanisms: inhibition of activation of T effector cells, GC-mediated Foxp3 induction, and Tregs being more resistant to GC (76).

GC treatment also affects B cells. Firstly, GC induce apoptosis in $\mathrm{B}$ cells at all developmental stages (78-80). In addition, GC suppress plasma cell differentiation potentially via downregulation of Blimp1 and $\operatorname{Bcl} 6(81,82)$. Finally, GC may also directly affect the production of IgG antibodies through inhibition of activation-induced cytidine deaminase (AICDA), an enzyme required for class switch recombination and somatic hypermutation (83). As a result of these GC-induced changes, GC reduce the number of plasma cell precursors and plasma cells and the level of anti-nuclear antibodies demonstrated in the murine MRL/lpr model for SLE (82). Importantly, the number of circulating B cells in human blood is also reduced upon GC treatment (84).

GC also impair dendritic cell (DC) maturation and function (85). DCs treated with GC increase their antigen uptake, decrease their expression of maturation markers (CD80, CD86) and decrease TNF- $\alpha$, IL-6, and IL-12 production which in turn decreases the induction of $\mathrm{T}$ cell responses $(85,86)$. GC treated DCs have also been described as tolerogenic with the ability to drive $\mathrm{T}$ cells toward a Treg phenotype, creating an increase in IL10 production $(87,88)$. As a result of these effects, GC enhance the clearance of dead cells and toxins, and increase scavenger function and phagocytosis. GC treatment also decreases the number of pDCs in the peripheral blood, which is important in SLE since they are key IFN- $\alpha$ producers (89). Following GC treatment, levels of IFN- $\alpha$ have been reported to be reduced to levels approximately 25 -fold below those seen in untreated healthy donors (89). As type I IFN is implicated in disease severity and activity in SLE, control of pDC number and IFN$\alpha$ production by GC could be of benefit for the treatment of SLE. Of note, however, pDC IFN production has been reported to be resistant to GC inhibition in SLE, because of TLR-induced NF- $\kappa \mathrm{B}$ overcoming GC inhibitory effects (90); it is noteworthy that the IFN signature recognized as associated with SLE is still present in GC-treated patients. Were it to be proven that SLErelated IFN activity was resistant to GC, this would provide a novel target for "assisting" the effects of GC in SLE, for example by reversing factors associated with their inability to suppress IFN in this disease.

Treatment with GC increases the phagocytic ability of macrophages, a finding demonstrated in human macrophages and mouse models $(91,92)$. This process is assisted by up regulation of mannose receptor (CD206) and scavenger receptors (CD163) on macrophages and enhancement of IL-10 production $(93,94)$ in response to GC. Significantly for SLE, GC treatment thus also increases the phagocytosis of apoptotic neutrophils by macrophages 


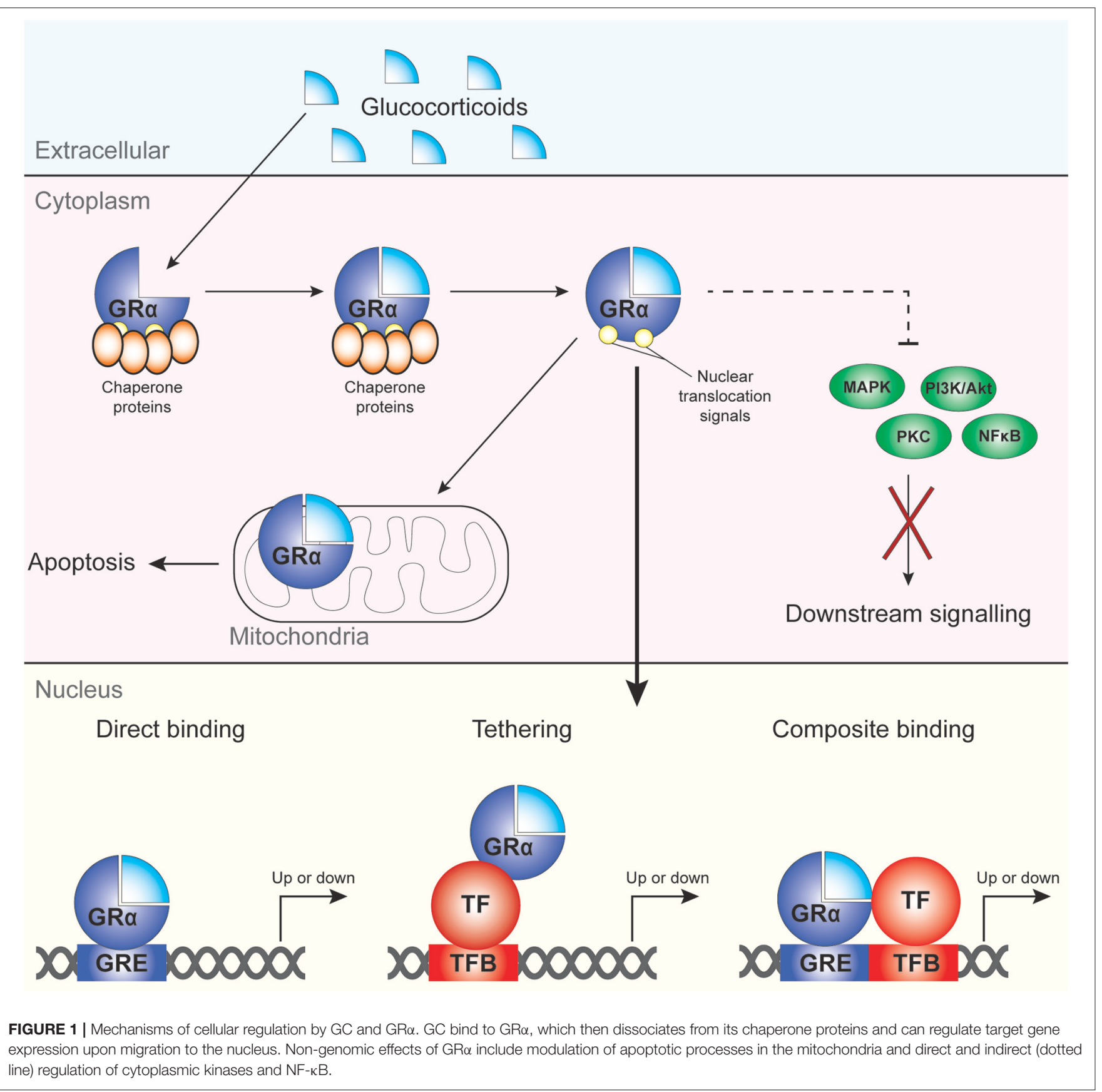

(95), thus reducing the number of NETs and reducing their pro-inflammatory impact. GC also have direct immune modulating effects on neutrophils, dampening their activation through several mechanisms including anti-apoptotic effects (96), inducing detachment via effects on cell surface CD62L (97) and reducing expression of pro-inflammatory cytokines (98).

This wide array of immunomodulation entrained by GC underpins reliance on GC treatment in SLE. Thus, it is imperative that any replacement for GC is able to target multiple immune pathways and provide potent anti-inflammatory immune cell regulation (Figure 2). The ability to achieve these effects without causing the devastating metabolic adverse effects of GC has been described as the "holy grail" of inflammatory pharmacology (99).

\section{COULD GC-INDUCED LEUCINE ZIPPER (GILZ) TARGETING BE A REPLACEMENT FOR GC TREATMENT IN SLE?}

GILZ mRNA expression negatively correlates with SLE disease activity (100) and we have demonstrated that active SLE is associated with lower intracellular GILZ protein levels across multiple leukocyte subsets (11). These findings 


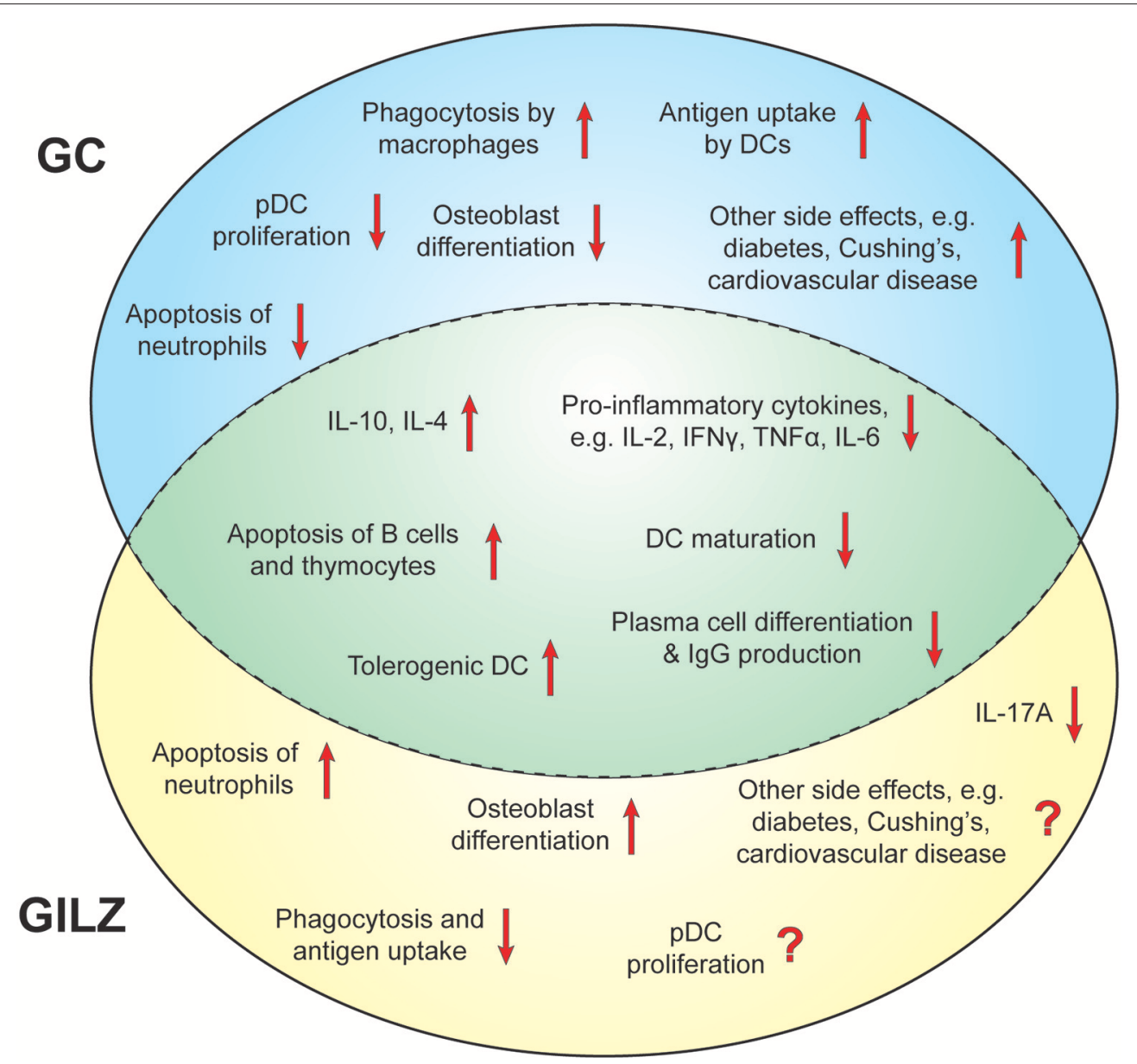

FIGURE 2 | Immunomodulatory effects of GC and GILZ. Overview of the effects of GILZ and GC that contribute to their suppressive capacities and potential side effects in SLE. Unique effects of GC are depicted in the blue circle, unique effects of GILZ in the yellow circle. Shared actions between GC and GILZ are shown in the middle green area.

suggest the possibility that GILZ deficiency contributes to SLE immunopathogenesis, and conversely that GILZ augmentation might be effective in SLE.

GILZ, also known as TSC22 domain family protein 3 $(T S C 22 D 3)$ is a 134aa protein in humans. It contains three main regions: an $\mathrm{N}$-terminal domain with a tuberous sclerosis complex (TSC) domain, a leucine zipper, and a proline-rich Cterminal domain. The leucine zipper domain of GILZ largely mediates the homodimerization of GILZ, a requirement for many of its functions (101). The N-terminal and C-terminal domains of GILZ are regions where several protein-protein interactions occur, particularly with transcriptional and signaling molecules. These interactions are critical for the immunosuppressive effects of GILZ.

GILZ has been demonstrated to modulate immune cell activation and promote an anti-inflammatory phenotype (102, 103). This is mediated in part by inhibiting the nuclear translocation and DNA binding of NF- $\kappa$ B, largely through direct binding of the C-terminus of GILZ to the p65 subunit of NF$\kappa \mathrm{B}(101,103)$. Additionally, GILZ binds to AP-1, a transcription factor consisting of c-Jun and c-Fos with a broad range of functions on immune cell activation (104), GILZ binds to AP-1 through its N-terminal domain and prevents AP-1 from binding to its target DNA (105).

GILZ also interferes with other cellular signaling molecules, such as extracellular signal-regulated kinases (ERK). The ERK pathway is involved in multiple regulatory processes and is key to many immune cell functions included cell differentiation, proliferation, survival, apoptosis, transcription and metabolism (106). GILZ suppresses the ERK pathway via direct binding to Ras via its TSC domain and, depending on the level of Ras activation, via formation of a trimeric complex with Ras and $\operatorname{Raf}(107,108)$. This results in a decrease in activation of downstream targets of Ras and Raf, for example the ERK1/2 and protein kinase B (AKT/PKB) (107), and a subsequent decrease in cell proliferation.

\section{The Effect of GILZ on Immune Events Involved in SLE Pathogenesis}

As noted above, GILZ regulates pivotal transcription factors and cellular pathways involved in immune-inflammatory responses. Notably, many of these transcription factor interactions of GILZ, 
mimic the transrepressive effects of GC. This raises the potential of GILZ as a replacement for GC. A comparison between the effects of GILZ and GC in animal models of inflammatory diseases has been summarized previously (39).

GILZ has a pro-apoptotic effect on thymocytes similar to GC, as demonstrated by GILZ overexpression systems in mouse models. GILZ overexpression led to a reduction of $\mathrm{Bcl}-\mathrm{xL}$ expression and increased activation of caspase 3 and 8 (109). This results in a decrease in $\mathrm{CD} 4^{+} \mathrm{CD} 8^{+}$thymocytes. However, in $\mathrm{T}$ cells, GILZ can exert an anti-apoptotic effect, inhibiting antiCD3 antibody-induced cell apoptosis through binding to AP-1 (110). This leads to inhibition of FasL expression and inhibition of apoptotic pathways $(105,108)$.

Similar to GC, GILZ also promotes a Th2 over a Th1 phenotype in $\mathrm{T}$ cells. This was demonstrated in activated $\mathrm{CD}^{+}{ }^{+} \mathrm{T}$ cells from GILZ transgenic mice, which had increased expression of Th2 transcription factors GATA-3 and STAT6 but decreased production of the Th1 transcription factor T-bet (111). Additionally, GILZ induced a Th2 cytokine profile with increased IL-4, IL-5, IL-10, and IL-13 production and a reduction in IFN- $\gamma$ production. Supporting the role of GILZ in reducing Th1 cytokine production, mouse GILZ-deficient T cells show an increase in IFN- $\gamma$ production compared to wildtype T cells (112). GILZ also induces the production of Tregs and IL-10, further promoting a regulatory environment and increased production of IL-10 (113).

GILZ regulates cytokine production in $\mathrm{T}$ cells and other immune cells largely through inhibition of the transcriptional activity of AP-1, NF- $\mathrm{B}$, and NFAT transcriptional factors. For example, GILZ binding to NF- $\kappa \mathrm{B}$ results in a reduction in IL-2 and IL-2R $(103,114)$ and regulation of T cell activation (103) and also regulates IL-2 production via binding to AP-1. In human $\mathrm{T}$ cells GILZ also inhibits IL- 5 production via AP- 1 binding, resulting in a negative correlation between expression of IL5 and GILZ (115). These findings are particularly important for reducing inflammation in a chronic inflammatory disease like SLE, which is characterized by hyperactive $\mathrm{T}$ cell responses including $\mathrm{T}$ cell-dependent $\mathrm{B}$ cell activation.

Next to the classical Th1 and Th2 cells, GILZ also affects Th17 cells. We and others have shown that GILZ inhibits the differentiation of Th17 cells (116, 117). Mechanistically, this is thought to be mediated via direct binding of GILZ to the promoters of Th17 genes including Batf, Stat3, Irf4, and ROR- $\gamma$ t (117). Knockdown of GILZ increases expression of Th17 transcription factors (Rorc, Rbpj, and Batf), cytokines (IL-17A and IL-21) and also reduces Foxp3 expression (117). Furthermore, we have demonstrated, in studies of GILZ-deficient mice, that endogenous GILZ inhibits production of Th17inducing cytokines IL-1 $\beta$, IL-23, and IL- 6 from bone marrowderived dendritic cells, further limiting Th17 differentiation (116). Also, using the imiquimod-induced psoriasis model, we have found that GILZ deficiency increases IL-17A, IL-1 $\beta$, IL-6, and IL-23 in skin lesions. However, these findings may contrast the results of Carceller et al. that demonstrate lesional expression IL-17F, IL-22, and IL-23 increases upon systemic exogenous GILZ overexpression in the same model $(116,118)$. In human psoriatic lesions, GILZ expression is decreased and correlates negatively with Th17-related pro-inflammatory cytokines IL-23, IL-17A, IL-22, and STAT3 demonstrated in human psoriatic lesions (116).

SLE is characterized by hyperactive B cells and a failure of $B$ cell tolerance to self-antigens. GC have suppressive and cytotoxic effects on B cells $(78,119)$ and GILZ is able to mimic several of these effects, inhibiting cell proliferation, activation, differentiation, IgG production, and apoptosis $(80,81)$. We have also demonstrated a reduction in GILZ expression in B cells from both SLE patients and in a lupus prone mouse model (11). Our study also demonstrated that GILZ deficiency results in lupuslike autoimmunity in aged mice, manifesting as excessive B cell responses to $\mathrm{T}$ dependent stimulation and the upregulation of genes which promote germinal center B cell phenotype, lupus susceptibility genes and genes for B cell survival and proliferation (11). The consequences of GILZ deficiency in vivo in these experiments included spontaneous production of lupus-related autoantibodies including ANA, anti-dsDNA, and anti-Sm, as well as immune complex glomerulonephritis. Additionally, treatment of human B cells with GILZ protein suppressed their responsiveness to $\mathrm{T}$ dependent stimuli, providing more evidence that GILZ is a regulator of B cell activity and proofof-principle that therapeutic supplementation of GILZ could negative regulate $B$ cell activation in SLE.

Deletion of GILZ in mouse models has also been demonstrated to result in an increase in B cell numbers in bone marrow, blood, and lymph nodes (119). This is a corollary of the effect on B cell numbers of GC, which cause a decrease of $B$ cells in several organs and circulation. Thus, GILZ is a key mediator in the regulation of $B$ cell survival. This increase in B cell survival in GILZ-deficient mouse models correlates with an increased NF- $\mathrm{B}$ activity and Bcl-2 expression (119). GILZ regulation of inflammatory immune responses is further demonstrated in a colitis mouse model where GILZ deficient mice had increased IFN- $\gamma$ production by $\mathrm{B}$ cells, increased $\mathrm{CD}^{+} \mathrm{T}$ cell activation and enhanced AP-1 activity (120). These mouse models demonstrate proof of principle for the potential therapeutic effect of GILZ in regulating $B$ celldependent inflammatory diseases, wherein increased colitis in the setting of GILZ deficiency was reversible via GILZ protein administration (120).

The ability of GILZ to modulate the activation of several signal transduction pathways also affects the maturation of DCs. This is supported in GILZ overexpression models, where GILZ mimicked the inhibitory effects of GC on human DC maturation and activation. For example, GILZ caused a decrease in the expression of DC activation markers (CD80, CD86, and CD83), less IL-12 production and increased IL-10 production $(121,122)$. GILZ overexpression in DCs can also cause DCs to favor the induction of Tregs over T effector cells (123). Thus, it is suggested that GILZ supports an alternative pathway of activation and differentiation of DCs, leading to a more tolerogenic DC phenotype (122). This has also been demonstrated in mouse studies wherein GILZ affected splenic DC function by inhibiting macropinocytosis and inhibited antigen uptake by CD8a-positive mouse DCs, which had the highest level of GILZ of the splenic DC subsets (124). 
Modulation of the NF-kB pathway by GILZ also reduces macrophage activation, as illustrated by the reduced expression of CD80, CD86, TLR 2, and chemokines CCL5 and CCL3 (102). TLR 4 stimulation of GILZ deficient bone marrow derived macrophages results in enhanced NF- $\mathrm{KB}$ and AP-1 activity (125). As well as cytokine and chemokine production, GILZ also decreases the phagocytic capacity of macrophages (126). Interestingly, this effect is opposite to the effect of GC, which promote phagocytosis by macrophages. Additionally, GILZ also regulates several neutrophil functions including their activation through inhibition of the MAPK pathway (127), their migration (via annexin A1) (128) and apoptosis (associated with caspases 3 , $8,9)(129,130)$.

Interestingly, GILZ is not only regulated by GC, but can also be induced by IL-4, IL-10 and curcumin (102, 131-133). Furthermore, studies in macrophages, in vitro, ex vivo, and in vivo, have shown that TLR $1 / 2$ and TLR 4 stimulation reduce GILZ mRNA and protein levels $(126,134)$. Similar findings were reported in T cells, where TCR triggering reduces GILZ expression (103). These data indicate a feedback loop where GILZ is higher in unactivated immune cells and decreases upon their activation.

\section{THERAPEUTIC POTENTIAL AND DEVELOPMENT OF GILZ DELIVERY}

In previous attempts to find safer GC replacement therapies, much research has focussed on selective glucocorticoid receptor agonists and modulators, termed SEGRAMs (135). These compounds were designed to address the hypothesis that GR transactivation was responsible for GC-induced adverse effects, and GR transrepression for anti-inflammatory effects, such that compounds targeting transrepression might be powerfully therapeutic without the side effects of GC. However, it is now known that transactivation effects of GC, such as the induction of GILZ and other GC-induced immune regulators such as DUSP1 (136), are required for the anti-inflammatory effects of GC in vivo (137), while adverse effects from GC such as osteoporosis are mediated by both transactivation and transrepression (138).

The potential of GILZ to be the target of a new therapeutic for SLE not only relies upon its immunosuppressive ability but also on a lack of detrimental metabolic effects. Evidence to date is encouraging, although more research is needed. GCs have an inhibitory effect on osteoblast formation, which accounts partially for the rapid bone loss seen in GC-treated patients (139). In contrast, GILZ may exert the opposite effect. Mesenchymal stem cells (MSC) can differentiate into osteoblasts or adipocytes; GILZ expression in MSC increases osteogenic differentiation and inhibits adipocyte formation $(140,141)$. Furthermore, osteogenic differentiation and development has been shown to be reduced by silencing GILZ (141). The underlying mechanism for this shift in differentiation includes GILZ binding to the tandem repeat of the CCAAT/enhancer binding protein (C/EBP) site in the promotor of peroxisome proliferator-activated receptor gamma2 (PPAR $\gamma 2)$. This decreases PPAR $\gamma 2$ expression, a regulator of adipocyte differentiation $(140,141)$. Thus, GILZ may play a role in enhancing or stabilizing bone density, rather than inhibiting osteoblast formation and inducing rapid bone loss as seen in GC treated patients. Furthermore, osteoblast-restricted GILZ overexpression resulted in a phenotype characterized by high bone mass, increased bone formation, and increased osteoblast numbers (142). Whereas, the effects of GILZ on osteoblast differentiation are opposite to the effects of GC, a study by Bruscoli et al. indicates that GILZ is required for the anti-myogenic effects of GC on skeletal muscle cells (143). Since both GILZ and GR expression are correlated with protein consumption, this may be mediated by increased protein catabolism that is associated with muscle atrophy (144). In relation to other metabolic adverse effects of GC, such as gluconeogenesis, skin thinning, cataracts and/or cardiovascular side effects, it is still unknown whether GILZ is protective or contributory. Therefore, further studies are essential to determine whether GILZ induces other metabolic adverse effects of GC in order to evaluate its value as a GC replacement therapy.

Studies to date investigating the clinical potential of GILZbased therapies for autoimmune disease have largely used mouse disease models. Proof of principle studies have demonstrated that local upregulation of GILZ expression through the administration of adeno-associated virus vector system on the day of disease onset inhibits arthritis in the collageninduced arthritis model (112). Additionally, transgenic mouse models, creating an overexpression of GILZ in T cells, were protective against Th1 mediated colitis (111). In vitro, a fusion protein of GILZ with a protein transduction domain $(\mathrm{HHpH}-$ GILZ), allowing entry of exogenously applied GILZ to the cell, was able to induce inhibition of Th17 activation and B cell activation $(11,116)$. Similarly, delivery of GILZ using a transactivator of transcription (TAT)-GILZ fusion protein was able to protect against dinitrobenzene sulfonic acid-induced colitis (145). However, it should be noted that systemic GILZ overexpression may not be beneficial for all disease states. For example, in the murine imiquimod-induced psoriasis model both GILZ deficiency (116) and GILZ transgenic overexpression led to worsening of skin inflammation (118); this is of interest given the clinical finding of glucocorticoid-withdrawal induced flares of psoriasis in humans. Thus, further studies are needed to address the therapeutic utility of GILZ in different disease settings and during established disease states.

Studies utilizing truncated regions of the GILZ protein have also demonstrated therapeutic promise. One study used a peptide targeting the C-terminus region of GILZ 115137aa from the mouse GILZ sequence. This region binds to the p65 subunit of NF- $\mathrm{kB}$, inhibiting NF- $\mathrm{kB}$ translocation to the nucleus and DNA binding (146). This peptide was demonstrated to have therapeutic potential in experimental autoimmune encephalitis (EAE), where it decreased $\mathrm{T}$ cell proliferation, decreased IL-12, IFN- $\gamma$, and IL-17 production and increased IL-10 production (146). Furthermore, the GILZ peptide decreased T-bet mRNA and increased GATA-3 mRNA levels creating a Th2 $\mathrm{T}$ cell phenotype. A single dose of GILZ peptide on day of disease induction was protective against the development of EAE in mice (146). Another study, utilizing a similar region of GILZ 98-134aa of the 
human GILZ sequence, demonstrated the anti-inflammatory activity GILZ (147). Here GILZ administration similarly suppressed the nuclear translocation of NF- $\kappa \mathrm{B}$, inhibited cytokine production and inhibited the gliosis of Muller cells (147).

Although these studies utilizing the C-terminus of GILZ are promising for use of a GILZ-based therapy in autoimmune diseases, it should be noted that the N-terminal domain of GILZ is also important for inhibition of transcription factors and signaling pathways. Therefore, all or several regions of GILZ may be required for the potent regulation of multiple inflammatory immune responses, an essential requirement of a new SLE therapy. This implies that strategies targeting the endogenous expression of natural GILZ, or its degradation, may hold greater promise. A greater understanding of the mechanisms of regulation of GILZ and its gene targets is critical to advance this field. This knowledge is also important for a potential gene therapy approach to deliver GILZ, either via expressing peptides or the entire protein. An additional method which may hold promise as a future therapeutic mechanism could be to induce GILZ expression using small molecules. For example, two SEGRAM compounds under investigation, RU24858 and ORG 214007-0, induce GILZ (135). We consider that methods to induce GILZ expression that do not utilize the GR could avoid GR-dependent metabolic effects. Additionally, a GC replacement therapy which delivers or targets GILZ could alleviate the effects of GR downregulation by chronic GC dosing. Thus, evaluation of multiple pathways is required to lead to the development of a therapy to therapeutically induce GILZ. As GILZ is also a bona fide transcription factor (117), studies cataloging in full the gene targets of GILZ are also required in order to understand the targets for GILZ mimics, both for comprehending the potential for potent immune modifying effects as well as potential adverse effects.

\section{REFERENCES}

1. Connelly K, Morand EF, Hoi AY. Asian ethnicity in systemic lupus erythematosus: an Australian perspective. Intern Med J. (2012) 43:618-24. doi: 10.1111/imj.12070

2. Tsokos GC. Systemic lupus erythematosus. N Engl J Med. (2011) 365:211021. doi: 10.1056/NEJMra1100359

3. Yen EY, Singh RR. Brief report: lupus-an unrecognized leading cause of death in young females: a population-based study using nationwide death certificates, 2000-2015. Arthritis Rheumatol. (2018) 70:1251-5. doi: 10.1002/art.40512

4. Danza A, Ruiz-Irastorza G, Khamashta M. Glucocorticoid use and abuse in SLE. Rheumatology. (2012) 51:1145-53. doi: 10.1093/rheumatology/ker410

5. Tan EM, Cohen AS, Fries JF, Masi AT, McShane DJ, Rothfield NF, et al. The 1982 revised criteria for the classification of systemic lupus erythematosus. Arthritis Rheum. (1982) 25:1271-7. doi: 10.1002/art.1780251101

6. Yung S, Chan TM. Mechanisms of kidney injury in lupus nephritis - the role of anti-dsDNA antibodies. Front Immunol. (2015) 6:475. doi: 10.3389/fimmu.2015.00475

7. Kirou KA, Lee C, George S, Louca K, Peterson MG, Crow MK. Activation of the interferon-alpha pathway identifies a subgroup of systemic lupus erythematosus patients with distinct serologic features and active disease. Arthritis Rheum. (2005) 52:1491-503. doi: 10.1002/art.21031

\section{SUMMARY}

SLE is a complex chronic autoimmune disease characterized by heterogeneous clinical features as a consequence of a failure of multiple immune checkpoints. This leads to hyperactive $\mathrm{B}$ and $\mathrm{T}$ cell responses, the production of autoantibodies and formation of immune complexes, activation of innate immunity, and consequently inflammation, organ damage, morbidity and mortality. Currently there is no cure for SLE and mainstay treatment with GC causes debilitating adverse effects. GILZ represents a novel target for the induction of a potent anti-inflammatory and immune suppressive response targeting multiple signaling pathways and immune cells. Proof of principle studies have demonstrated GILZ to have significant therapeutic effects in animal models of autoimmune disease. The immunosuppressive effects of GILZ are broadly similar to those of GC and to date, other than myogenic effects, there is no evidence of adverse metabolic effects of GILZ. Further research is required, to determine whether a GILZ based therapy would have metabolic effects, and into the molecular mechanisms for the induction and targeting of GILZ. The idea of a new therapy which enhances GILZ expression, and/or targets the same molecular pathways as GILZ, is a very attractive one with the potential to provide a critically-needed replacement for GC therapy in SLE.

\section{AUTHOR CONTRIBUTIONS}

JF and EM designed the review. JF and WD wrote the review. All authors critically revised the manuscript and approved it for publication.

\section{FUNDING}

This work was financially supported by the Lupus Research Alliance and Arthritis Australia.

8. Baechler EC, Batliwalla FM, Karypis G, Gaffney PM, Ortmann WA, Espe KJ, et al. Interferon-inducible gene expression signature in peripheral blood cells of patients with severe lupus. Proc Natl Acad Sci USA. (2003) 100:2610-5. doi: 10.1073/pnas.0337679100

9. Crow MK, Kirou KA, Wohlgemuth J. Microarray analysis of interferon-regulated genes in SLE. Autoimmunity. (2003) 36:481-90. doi: 10.1080/08916930310001625952

10. Bosch X. Systemic lupus erythematosus and the neutrophil. N Engl J Med. (2011) 365:758-60. doi: 10.1056/NEJMcibr1107085

11. Jones SA, Toh AEJ, Odobasic D, Oudin M-AV, Cheng Q, Lee JPW, et al. Glucocorticoid-induced leucine zipper (GILZ) inhibits B cell activation in systemic lupus erythematosus. Ann Rheum Dis. (2016) 75:739-47. doi: 10.1136/annrheumdis-2015-207744

12. Sheriff A, Kalden JR, Munoz LE, Herrmann M, Voll RE, Franz S, et al. SLE-a disease of clearance deficiency? Rheumatology. (2005) 44:1101-7. doi: 10.1093/rheumatology/keh693

13. Christensen SR, Shupe J, Nickerson K, Kashgarian M, Flavell RA, Shlomchik MJ. Toll-like receptor 7 and TLR9 dictate autoantibody specificity and have opposing inflammatory and regulatory roles in a murine model of lupus. Immunity. (2006) 25:417-28. doi: 10.1016/j.immuni.2006. 07.013

14. Davis LS, Hutcheson J, Mohan C. The role of cytokines in the pathogenesis and treatment of systemic lupus erythematosus. $J$ 
Interferon Cytokine Res. (2011) 31:781-9. doi: 10.1089/jir.2011. 0047

15. Crow MK, Olferiev M, Kirou KA. Targeting of type I interferon in systemic autoimmune diseases. Transl Res. (2015) 165:296-305. doi: 10.1016/j.trsl.2014.10.005

16. Oliveira L, Sinicato NA, Postal M, Appenzeller S, Niewold TB. Dysregulation of antiviral helicase pathways in systemic lupus erythematosus. Front Genet. (2014) 5:418. doi: 10.3389/fgene.2014. 00418

17. Farkas L, Beiske K, Lund-Johansen F, Brandtzaeg P, Jahnsen FL. Plasmacytoid dendritic cells (natural interferon- alpha/beta-producing cells) accumulate in cutaneous lupus erythematosus lesions. Am J Pathol. (2001) 159:237-43. doi: 10.1016/S0002-9440(10)61689-6

18. Blanco P, Palucka AK, Gill M, Pascual V, Banchereau J. Induction of dendritic cell differentiation by IFN- $\alpha$ in systemic lupus erythematosus. Science. (2001) 294:1540-3. doi: 10.1126/science. 1064890

19. Martinelli S, Urosevic M, Daryadel A, Oberholzer PA, Baumann C, Fey MF, et al. Induction of genes mediating interferon-dependent extracellular trap formation during neutrophil differentiation. J Biol Chem. (2004) 279:4412332. doi: 10.1074/jbc.M405883200

20. Garcia-Romo GS, Caielli S, Vega B, Connolly J, Allantaz F, Xu Z, et al. Netting neutrophils are major inducers of type I IFN production in pediatric systemic lupus erythematosus. Sci Transl Med. (2011) 3:73ra20. doi: 10.1126/scitranslmed.3001201

21. Brinkmann V, Reichard U, Goosmann C, Fauler B, Uhlemann Y, Weiss DS, et al. Neutrophil extracellular traps kill bacteria. Science. (2004) 303:1532-5. doi: 10.1126/science.1092385

22. Armstrong DJ, Crockard AD, Wisdom BG, Whitehead EM, Bell AL. Accelerated apoptosis in SLE neutrophils cultured with anti-dsDNA antibody isolated from SLE patient serum: a pilot study. Rheumatol Int. (2006) 27:153-6. doi: 10.1007/s00296-006-0219-z

23. Koshy M, Berger D, Crow MK. Increased expression of CD40 ligand on systemic lupus erythematosus lymphocytes. J Clin Invest. (1996) 98:826-37. doi: 10.1172/JCI118855

24. Simpson N, Gatenby PA, Wilson A, Malik S, Fulcher DA, Tangye SG, et al. Expansion of circulating $\mathrm{T}$ cells resembling follicular helper $\mathrm{T}$ cells is a fixed phenotype that identifies a subset of severe systemic lupus erythematosus. Arthritis Rheum. (2010) 62:234-44. doi: 10.1002/art.25032

25. Kaul A, Gordon C, Crow MK, Touma Z, Urowitz MB, van Vollenhoven R, et al. Systemic lupus erythematosus. Nat Rev Dis Primers. (2016) 2:16039. doi: $10.1038 /$ nrdp. 2016.40

26. Dubey AK, Handu SS, Dubey S, Sharma P, Sharma KK, Ahmed QM. Belimumab: First targeted biological treatment for systemic lupus erythematosus. J Pharmacol Pharmacother. (2011) 2:317-9. doi: 10.4103/0976-500X.85930

27. Cruz-Topete D, Cidlowski JA. Glucocorticoids: molecular mechanisms of action. In: Riccardi C, Levi-Schaffer F, Tiligada E, editors. Immunopharmacology and Inflammation. Cham: Springer International Publishing (2018). p. 249-66.

28. Nataraja C, Morand EF. Systemic glucocorticoid therapy in SLE. In: Wallace DJ, Hahn BH, editors. Dubois' Systemic Lupus Erythematosus. New York, NY: Elsevier (2019). p. 661-72.

29. Apostolopoulos D, Morand EF. It hasn't gone away: the problem of glucocorticoid use in lupus remains. Rheumatology (Oxford). (2017) 56(suppl. 1):i114-i22. doi: 10.1093/rheumatology/kew406

30. Vincent FB, Morand EF, Schneider P, Mackay F. The BAFF/APRIL system in SLE pathogenesis. Nat Rev Rheumatol. (2014) 10:365-73. doi: 10.1038/nrrheum.2014.33

31. van Vollenhoven RF, Petri M, Wallace DJ, Roth DA, Molta CT, Hammer $\mathrm{AE}$, et al. Cumulative corticosteroid dose over fifty-two weeks in patients with systemic lupus erythematosus: pooled analyses from the phase III belimumab trials. Arthritis Rheumatol. (2016) 68:2184-92. doi: 10.1002/art. 39682

32. Wallace DJ, Strand V, Merrill JT, Popa S, Spindler AJ, Eimon A, et al. Efficacy and safety of an interleukin 6 monoclonal antibody for the treatment of systemic lupus erythematosus: a phase II doseranging randomised controlled trial. Ann Rheum Dis. (2017) 76:534-42. doi: 10.1136/annrheumdis-2016-209668
33. Rhen T, Cidlowski JA. Antiinflammatory action of glucocorticoidsnew mechanisms for old drugs. N Engl J Med. (2005) 353:1711-23. doi: 10.1056/NEJMra050541

34. Nicolaides NC, Galata Z, Kino T, Chrousos GP, Charmandari E. The human glucocorticoid receptor: molecular basis of biologic function. Steroids. (2010) 75:1-12. doi: 10.1016/j.steroids.2009.09.002

35. Oakley RH, Cidlowski JA. The biology of the glucocorticoid receptor: new signaling mechanisms in health and disease. J Allergy Clin Immunol. (2013) 132:1033-44. doi: 10.1016/j.jaci.2013.09.007

36. Weikum ER, Knuesel MT, Ortlund EA, Yamamoto KR. Glucocorticoid receptor control of transcription: precision and plasticity via allostery. Nat Rev Mol Cell Biol. (2017) 18:159-74. doi: 10.1038/nrm.2016.152

37. Kumar R, Thompson EB. Gene regulation by the glucocorticoid receptor: structure:function relationship. J Steroid Biochem Mol Biol. (2005) 94:38394. doi: 10.1016/j.jsbmb.2004.12.046

38. Petrillo MG, Bortner CD, Cidlowski JA. Glucocorticoids: inflammation and immunity. In: Geer EB, editor. The Hypothalamic-Pituitary-Adrenal Axis in Health and Disease: Cushing's Syndrome and Beyond. Cham: Springer International Publishing (2017). p. 43-63.

39. Cheng Q, Morand E, Yang YH. Development of novel treatment strategies for inflammatory diseases-similarities and divergence between glucocorticoids and GILZ. Front Pharmacol. (2014) 5:169. doi: 10.3389/fphar.2014.00169

40. Luypaert A, Vanden Berghe W, Tavernier J, Libert C, De Bosscher K. Strategies and compounds to circumvent glucocorticoid-induced side effects. In: Riccardi C, Levi-Schaffer F, Tiligada E, editors. Immunopharmacology and Inflammation. Cham: Springer International Publishing (2018). p. 283-305.

41. Muzikar KA, Nickols NG, Dervan PB. Repression of DNA-binding dependent glucocorticoid receptor-mediated gene expression. Proc Natl Acad Sci USA. (2009) 106:16598-603. doi: 10.1073/pnas.09091 92106

42. Zhang G, Zhang L, Duff GW. A negative regulatory region containing a glucocorticosteroid response element (nGRE) in the human interleukin1beta gene. DNA Cell Biol. (1997) 16:145-52. doi: 10.1089/dna.1997.16.145

43. Nissen RM, Yamamoto KR. The glucocorticoid receptor inhibits NFkappaB by interfering with serine-2 phosphorylation of the RNA polymerase II carboxy-terminal domain. Genes Dev. (2000) 14:2314-29. doi: $10.1101 / \operatorname{gad} .827900$

44. Yang-Yen HF, Chambard JC, Sun YL, Smeal T, Schmidt TJ, Drouin J, et al. Transcriptional interference between c-Jun and the glucocorticoid receptor: mutual inhibition of DNA binding due to direct protein-protein interaction. Cell. (1990) 62:1205-15. doi: 10.1016/0092-8674(90)90396-V

45. Schule R, Rangarajan P, Kliewer S, Ransone LJ, Bolado J, Yang N, et al. Functional antagonism between oncoprotein c-Jun and the glucocorticoid receptor. Cell. (1990) 62:1217-26. doi: 10.1016/0092-8674(90)9 0397-W

46. Panettieri RA, Schaafsma D, Amrani Y, Koziol-White C, Ostrom R, Tliba O. Non-genomic effects of glucocorticoids: an updated view. Trends Pharmacol Sci. (2019) 40:38-49. doi: 10.1016/j.tips.2018.11.002

47. Ayyar VS, DuBois DC, Almon RR, Jusko WJ. Mechanistic multitissue modeling of glucocorticoid-induced leucine zipper regulation: integrating circadian gene expression with receptor-mediated corticosteroid pharmacodynamics. J Pharmacol Exp Ther. (2017) 363:45-57. doi: 10.1124/jpet.117.242990

48. Yoshida A, Noguchi T, Taniguchi S, Mitani Y, Ueda M, Urabe K, et al. Receptor dynamics and tyrosine aminotransferase induction during the course of chronic treatment of rats with glucocorticoid. Endocrinol Jpn. (1986) 33:769-75. doi: 10.1507/endocrj1954.33.769

49. Ramakrishnan R, DuBois DC, Almon RR, Pyszczynski NA, Jusko WJ. Pharmacodynamics and pharmacogenomics of methylprednisolone during 7-Day infusions in rats. J Pharmacol Exp Ther. (2002) 300:245-56. doi: $10.1124 /$ jpet.300.1.245

50. Ramakrishnan R, DuBois DC, Almon RR, Pyszczynski NA, Jusko WJ. Fifth-generation model for corticosteroid pharmacodynamics: application to steady-state receptor down-regulation and enzyme induction patterns during seven-day continuous infusion of methylprednisolone in rats. J Pharmacokinet Pharmacodyn. (2002) 29:1-24. doi: 10.1023/A:1015765201129 
51. Hollenberg SM, Weinberger C, Ong ES, Cerelli G, Oro A, Lebo R, et al. Primary structure and expression of a functional human glucocorticoid receptor cDNA. Nature. (1985) 318:635-41. doi: 10.1038/318635a0

52. Bledsoe RK, Montana VG, Stanley TB, Delves CJ, Apolito CJ, McKee DD, et al. Crystal structure of the glucocorticoid receptor ligand binding domain reveals a novel mode of receptor dimerization and coactivator recognition. Cell. (2002) 110:93-105. doi: 10.1016/S0092-8674(02)00817-6

53. Bamberger CM, Bamberger AM, de Castro M, Chrousos GP. Glucocorticoid receptor beta, a potential endogenous inhibitor of glucocorticoid action in humans. J Clin Invest. (1995) 95:2435-41. doi: 10.1172/JCI117943

54. Li LB, Leung DYM, Hall CF, Goleva E. Divergent expression and function of glucocorticoid receptor beta in human monocytes and T cells. J Leukoc Biol. (2006) 79:818-27. doi: 10.1189/jlb.0805466

55. Zhang X, Clark AF, Yorio T. Regulation of glucocorticoid responsiveness in glaucomatous trabecular meshwork cells by glucocorticoid receptorbeta. Investig Ophthalmol Vis Sci. (2005) 46:4607-16. doi: 10.1167/iovs. 05-0571

56. Oakley RH, Jewell CM, Yudt MR, Bofetiado DM, Cidlowski JA. The dominant negative activity of the human glucocorticoid receptor beta isoform. Specificity and mechanisms of action. J Biol Chem. (1999) 274:27857-66. doi: 10.1074/jbc.274.39.27857

57. Charmandari E, Chrousos GP, Ichijo T, Bhattacharyya N, Vottero A, Souvatzoglou E, et al. The human glucocorticoid receptor (hGR) beta isoform suppresses the transcriptional activity of hGRalpha by interfering with formation of active coactivator complexes. Mol Endocrinol. (2005) 19:52-64. doi: 10.1210/me.2004-0112

58. Lewis-Tuffin LJ, Jewell CM, Bienstock RJ, Collins JB, Cidlowski JA. Human glucocorticoid receptor beta binds RU-486 and is transcriptionally active. Mol Cell Biol. (2007) 27:2266-82. doi: 10.1128/MCB.01439-06

59. Kino T, Manoli I, Kelkar S, Wang Y, Su YA, Chrousos GP. Glucocorticoid receptor (GR) beta has intrinsic, GRalpha-independent transcriptional activity. Biochem Biophys Res Commun. (2009) 381:671-5. doi: 10.1016/j.bbrc.2009.02.110

60. Webster JC, Oakley RH, Jewell CM, Cidlowski JA. Proinflammatory cytokines regulate human glucocorticoid receptor gene expression and lead to the accumulation of the dominant negative beta isoform: a mechanism for the generation of glucocorticoid resistance. Proc Natl Acad Sci USA. (2001) 98:6865-70. doi: 10.1073/pnas.121455098

61. Leung DY, Hamid Q, Vottero A, Szefler SJ, Surs W, Minshall E, et al. Association of glucocorticoid insensitivity with increased expression of glucocorticoid receptor beta. J Exp Med. (1997) 186:1567-74. doi: 10.1084/jem.186.9.1567

62. Vazquez-Tello A, Halwani R, Hamid Q, Al-Muhsen S. Glucocorticoid receptor-beta up-regulation and steroid resistance induction by IL-17 and IL-23 cytokine stimulation in peripheral mononuclear cells. J Clin Immunol. (2013) 33:466-78. doi: 10.1007/s10875-012-9828-3

63. Goleva E, Li LB, Eves PT, Strand MJ, Martin RJ, Leung DY. Increased glucocorticoid receptor beta alters steroid response in glucocorticoidinsensitive asthma. Am J Respir Crit Care Med. (2006) 173:607-16. doi: 10.1164/rccm.200507-1046OC

64. Lee CK, Lee EY, Cho YS, Moon KA, Yoo B, Moon HB. Increased expression of glucocorticoid receptor beta messenger RNA in patients with ankylosing spondylitis. Korean J Inter Med. (2005) 20:146-51. doi: $10.3904 / \mathrm{kjim} .2005 .20 .2 .146$

65. Piotrowski P, Burzynski M, Lianeri M, Mostowska M, Wudarski M, Chwalinska-Sadowska H, et al. Glucocorticoid receptor beta splice variant expression in patients with high and low activity of systemic lupus erythematosus. Folia Histochem Cytobiol. (2007) 45:339-42.

66. Derijk RH, Schaaf MJ, Turner G, Datson NA, Vreugdenhil E, Cidlowski J, et al. A human glucocorticoid receptor gene variant that increases the stability of the glucocorticoid receptor beta-isoform mRNA is associated with rheumatoid arthritis. J Rheumatol. (2001) 28:2383-8.

67. Leventhal SM, Lim D, Green TL, Cantrell AE, Cho K, Greenhalgh DG. Uncovering a multitude of human glucocorticoid receptor variants: an expansive survey of a single gene. BMC Genet. (2019) 20:16. doi: 10.1186/s12863-019-0718-z

68. Adcock IM. Glucocorticoid-regulated transcription factors. Pulm Pharmacol Ther. (2001) 14:211-9. doi: 10.1006/pupt.2001.0283
69. Liberman AC, Refojo D, Druker J, Toscano M, Rein T, Holsboer F, et al. The activated glucocorticoid receptor inhibits the transcription factor Tbet by direct protein-protein interaction. FASEB J. (2007) 21:1177-88. doi: $10.1096 /$ fj.06-7452com

70. Ronnblom L, Alm GV. A pivotal role for the natural interferon alphaproducing cells (plasmacytoid dendritic cells) in the pathogenesis of lupus. J Exp Med. (2001) 194:F59-63. doi: 10.1084/jem.194. 12.559

71. Erlacher M, Knoflach M, Stec IEM, Böck G, Wick G, Wiegers GJ. TCR signaling inhibits glucocorticoid-induced apoptosis in murine thymocytes depending on the stage of development. Eur J Immunol. (2005) 35:3287-96. doi: $10.1002 /$ eji.200526279

72. Kalia V, Sarkar S. Regulation of effector and memory CD8 T cell differentiation by IL-2-a balancing act. Front Immunol. (2018) 9:2987. doi: $10.3389 /$ fimmu.2018.02987

73. Liao W, Lin J-X, Leonard WJ. Interleukin-2 at the crossroads of effector responses, tolerance, and immunotherapy. Immunity. (2013) 38:13-25. doi: 10.1016/j.immuni.2013.01.004

74. Liberman AC, Antunica-Noguerol M, Ferraz-de-Paula V, PalermoNeto J, Castro CN, Druker J, et al. Compound A, a dissociated glucocorticoid receptor modulator, inhibits T-bet (Th1) and induces GATA-3 (Th2) activity in immune cells. PLoS ONE. (2012) 7:e35155. doi: 10.1371/journal.pone.0035155

75. Liberman AC, Druker J, Refojo D, Holsboer F, Arzt E. Glucocorticoids inhibit GATA-3 phosphorylation and activity in T cells. FASEB J. (2009) 23:1558-71. doi: 10.1096/fj.08-121236

76. Petrillo MG, Fettucciari K, Montuschi P, Ronchetti S, Cari L, Migliorati G, et al. Transcriptional regulation of kinases downstream of the $\mathrm{T}$ cell receptor: another immunomodulatory mechanism of glucocorticoids. $B M C$ Pharmacol Toxicol. (2014) 15:35. doi: 10.1186/2050-6511-15-35

77. Miller AT, Wilcox HM, Lai Z, Berg LJ. Signaling through Itk promotes $\mathrm{T}$ helper 2 differentiation via negative regulation of T-bet. Immunity. (2004) 21:67-80. doi: 10.1016/j.immuni.2004.06.009

78. Gruver-Yates AL, Quinn MA, Cidlowski JA. Analysis of glucocorticoid receptors and their apoptotic response to dexamethasone in male murine B cells during development. Endocrinology. (2014) 155:463-74. doi: 10.1210/en.2013-1473

79. Voetberg BJ, Garvy BA, Mayer HK, King LE, Fraker PJ. Apoptosis accompanies a change in the phenotypic distribution and functional capacity of murine bone marrow B-cells chronically exposed to prednisolone. Clin Immunol Immunopathol. (1994) 71:190-8. doi: 10.1006/clin.1994.1071

80. Garvy BA, King LE, Telford WG, Morford LA, Fraker PJ. Chronic elevation of plasma corticosterone causes reductions in the number of cycling cells of the $\mathrm{B}$ lineage in murine bone marrow and induces apoptosis. Immunology. (1993) 80:587-92.

81. Haneda M, Owaki M, Kuzuya T, Iwasaki K, Miwa Y, Kobayashi T. Comparative analysis of drug action on B-cell proliferation and differentiation for mycophenolic acid, everolimus, and prednisolone. Transplantation. (2014) 97:405-12. doi: 10.1097/01.TP.0000441826.70687.f6

82. Yan SX, Deng XM, Wang QT, Sun XJ, Wei W. Prednisone treatment inhibits the differentiation of B lymphocytes into plasma cells in MRL/MpSlac-lpr mice. Acta Pharmacol Sin. (2015) 36:1367-76. doi: 10.1038/aps.2015.76

83. Benko AL, Olsen NJ, Kovacs WJ. Glucocorticoid inhibition of activationinduced cytidine deaminase expression in human B lymphocytes. Mol Cell Endocrinol. (2014) 382:881-7. doi: 10.1016/j.mce.2013.11.001

84. Slade JD, Hepburn B. Prednisone-induced alterations of circulating human lymphocyte subsets. J Lab Clin Med. (1983) 101:479-87.

85. Woltman AM, de Fijter JW, Kamerling SW, Paul LC, Daha MR, van Kooten C. The effect of calcineurin inhibitors and corticosteroids on the differentiation of human dendritic cells. Eur J Immunol. (2000) 30:1807-12. doi: 10.1002/1521-4141(200007)30:7\&lt;1807::AIDIMMU1807\&gt;3.0.CO;2-N

86. Chabot V, Martin L, Meley D, Sensebé L, Baron C, Lebranchu Y, et al. Unexpected impairment of TNF- $\alpha$-induced maturation of human dendritic cells in vitro by IL-4. J Transl Med. (2016) 14:93. doi: 10.1186/s12967-016-0848-2

87. Kapsenberg ML. Dendritic-cell control of pathogen-driven T-cell polarization. Nat Rev Immunol. (2003) 3:984-93. doi: 10.1038/nri1246 
88. Bosma BM, Metselaar HJ, Nagtzaam NM, de Haan R, Mancham S, van der Laan LJ, et al. Dexamethasone transforms lipopolysaccharide-stimulated human blood myeloid dendritic cells into myeloid dendritic cells that prime interleukin-10 production in T cells. Immunology. (2008) 125:91-100. doi: 10.1111/j.1365-2567.2008.02824.x

89. Shodell M, Siegal FP. Corticosteroids depress IFN-alpha-producing plasmacytoid dendritic cells in human blood. J Allergy Clin Immunol. (2001) 108:446-8. doi: 10.1067/mai.2001.117928

90. Guiducci C, Gong M, Xu Z, Gill M, Chaussabel D, Meeker T, et al. TLR recognition of self nucleic acids hampers glucocorticoid activity in lupus. Nature. (2010) 465:937-41. doi: 10.1038/nature09102

91. Liu Y, Cousin JM, Hughes J, Van Damme J, Seckl JR, Haslett C, et al. Glucocorticoids promote nonphlogistic phagocytosis of apoptotic leukocytes. J Immunol. (1999) 162:3639-46.

92. Giles KM, Ross K, Rossi AG, Hotchin NA, Haslett C, Dransfield I. Glucocorticoid augmentation of macrophage capacity for phagocytosis of apoptotic cells is associated with reduced p130Cas expression, loss of paxillin/pyk2 phosphorylation, and high levels of active rac. J Immunol. (2001) 167:976. doi: 10.4049/jimmunol.167.2.976

93. McColl A, Michlewska S, Dransfield I, Rossi AG. Effects of glucocorticoids on apoptosis and clearance of apoptotic cells. Sci World J. (2007) 7:1165-81. doi: $10.1100 /$ tsw.2007.224

94. Heasman SJ, Giles KM, Ward C, Rossi AG, Haslett C, Dransfield I. Glucocorticoid-mediated regulation of granulocyte apoptosis and macrophage phagocytosis of apoptotic cells: implications for the resolution of inflammation. J Endocrinol. (2003) 178:29-36. doi: 10.1677/joe.0.17 80029

95. McColl A, Bournazos S, Franz S, Perretti M, Morgan BP, Haslett C, et al. Glucocorticoids induce protein S-dependent phagocytosis of apoptotic neutrophils by human macrophages. J Immunol. (2009) 183:2167-75. doi: 10.4049/jimmunol.0803503

96. Kato T, Takeda Y, Nakada T, Sendo F. Inhibition by dexamethasone of human neutrophil apoptosis in vitro. Nat Immunity. (1995) 14:198-208.

97. Strausbaugh HJ, Rosen SD. A potential role for annexin 1 as a physiologic mediator of glucocorticoid-induced L-selectin shedding from myeloid cells. J Immunol. (2001) 166:6294-300. doi: 10.4049/jimmunol.166. 10.6294

98. Hirsch G, Lavoie-Lamoureux A, Beauchamp G, Lavoie J-P. Neutrophils are not less sensitive than other blood leukocytes to the genomic effects of glucocorticoids. PLoS ONE. (2012) 7:e44606. doi: 10.1371/journal.pone.0044606

99. Belvisi MG, Brown TJ, Wicks S, Foster ML. New Glucocorticosteroids with an improved therapeutic ratio? Pulm Pharmacol Ther. (2001) 14:221-7. doi: 10.1006/pupt.2001.0284

100. Mohammadi S, Ebadpour MR, Sedighi S, Saeedi M, Memarian A. Glucocorticoid-induced leucine zipper expression is associated with response to treatment and immunoregulation in systemic lupus erythematosus. Clin Rheumatol. (2017) 36:1765-72. doi: 10.1007/s10067-017-3711-9

101. Di Marco B, Massetti M, Bruscoli S, Macchiarulo A, Di Virgilio R, Velardi E, et al. Glucocorticoid-induced leucine zipper (GILZ)/NF-kappaB interaction: role of GILZ homo-dimerization and C-terminal domain. Nucleic Acids Res. (2007) 35:517-28. doi: 10.1093/nar/gkl1080

102. Berrebi D, Bruscoli S, Cohen N, Foussat A, Migliorati G, BouchetDelbos L, et al. Synthesis of glucocorticoid-induced leucine zipper (GILZ) by macrophages: an anti-inflammatory and immunosuppressive mechanism shared by glucocorticoids and IL-10. Blood. (2003) 101:729-38. doi: 10.1182/blood-2002-02-0538

103. Ayroldi E, Migliorati G, Bruscoli S, Marchetti C, Zollo O, Cannarile L, et al. Modulation of T-cell activation by the glucocorticoid-induced leucine zipper factor via inhibition of nuclear factor kappaB. Blood. (2001) 98:743-53. doi: 10.1182/blood.V98.3.743

104. Karin M, Liu Z-g, Zandi E. AP-1 function and regulation. Curr Opin Cell Biol. (1997) 9:240-6. doi: 10.1016/S0955-0674(97)80068-3

105. Mittelstadt PR, Ashwell JD. Inhibition of AP-1 by the glucocorticoidinducible protein GILZ. J Biol Chem. (2001) 276:29603-10. doi: 10.1074/jbc.M101522200
106. Ramos JW. The regulation of extracellular signal-regulated kinase (ERK) in mammalian cells. Int J Biochem Cell Biol. (2008) 40:2707-19. doi: 10.1016/j.biocel.2008.04.009

107. Ayroldi E, Zollo O, Bastianelli A, Marchetti C, Agostini M, Di Virgilio $\mathrm{R}$, et al. GILZ mediates the antiproliferative activity of glucocorticoids by negative regulation of Ras signaling. J Clin Invest. (2007) 117:1605-15. doi: 10.1172/JCI30724

108. Ayroldi E, Zollo O, Macchiarulo A, Di Marco B, Marchetti C, Riccardi C. Glucocorticoid-induced leucine zipper inhibits the Raf-extracellular signalregulated kinase pathway by binding to Raf-1. Mol Cell Biol. (2002) 22:792941. doi: 10.1128/MCB.22.22.7929-7941.2002

109. Delfino DV, Agostini M, Spinicelli S, Vito P, Riccardi C. Decrease of Bcl-xL and augmentation of thymocyte apoptosis in GILZ overexpressing transgenic mice. Blood. (2004) 104:4134-41. doi: 10.1182/blood-2004-03-0920

110. D’Adamio F, Zollo O, Moraca R, Ayroldi E, Bruscoli S, Bartoli A, et al. A new dexamethasone-induced gene of the leucine zipper family protects $\mathrm{T}$ lymphocytes from TCR/CD3-activated cell death. Immunity. (1997) 7:80312. doi: 10.1016/S1074-7613(00)80398-2

111. Cannarile L, Fallarino F, Agostini M, Cuzzocrea S, Mazzon E, Vacca $\mathrm{C}$, et al. Increased GILZ expression in transgenic mice up-regulates Th-2 lymphokines. Blood. (2006) 107:1039-47. doi: 10.1182/blood-200505-2183

112. Ngo D, Beaulieu E, Gu R, Leaney A, Santos L, Fan H, et al. Divergent effects of endogenous and exogenous glucocorticoid-induced leucine zipper in animal models of inflammation and arthritis. Arthritis Rheum. (2013) 65:1203-12. doi: 10.1002/art.37858

113. Bereshchenko O, Coppo M, Bruscoli S, Biagioli M, Cimino M, Frammartino $\mathrm{T}$, et al. GILZ promotes production of peripherally induced treg cells and mediates the crosstalk between glucocorticoids and TGF$\beta$ signaling. Cell Rep. (2014) 7:464-75. doi: 10.1016/j.celrep.2014. 03.004

114. Delfino DV, Agostini M, Spinicelli S, Vacca C, Riccardi C. Inhibited cell death, NF-kappaB activity and increased IL-10 in TCR-triggered thymocytes of transgenic mice overexpressing the glucocorticoid-induced protein GILZ. Int Immunopharmacol. (2006) 6:1126-34. doi: 10.1016/j.intimp.2006. 02.001

115. Arthaningtyas E, Kok CC, Mordvinov VA, Sanderson CJ. The conserved lymphokine element 0 is a powerful activator and target for corticosteroid inhibition in human interleukin-5 transcription. Growth Factors. (2005) 23:211-21. doi: 10.1080/08977190500178638

116. Jones SA, Perera DN, Fan H, Russ BE, Harris J, Morand EF. GILZ regulates Th17 responses and restrains IL-17-mediated skin inflammation. J Autoimmun. (2015) 61:73-80. doi: 10.1016/j.jaut.2015.05.010

117. Yosef N, Shalek AK, Gaublomme JT, Jin H, Lee Y, Awasthi A, et al. Dynamic regulatory network controlling TH17 cell differentiation. Nature. (2013) 496:461. doi: 10.1038/nature11981

118. Carceller E, Ballegeer M, Deckers J, Riccardi C, Bruscoli S, Hochepied $\mathrm{T}$, et al. Overexpression of glucocorticoid-induced leucine zipper (GILZ) increases susceptibility to Imiquimod-induced psoriasis and involves cutaneous activation of TGF- $\beta 1$. Sci Rep. (2016) 6:38825. doi: 10.1038/srep 38825

119. Bruscoli S, Biagioli M, Sorcini D, Frammartino T, Cimino $M$, Sportoletti P, et al. Lack of glucocorticoid-induced leucine zipper (GILZ) deregulates B-cell survival and results in B-cell lymphocytosis in mice. Blood. (2015) 126:1790-801. doi: 10.1182/blood-2015-03631580

120. Bruscoli S, Sorcini D, Flamini S, Gagliardi A, Adamo F, Ronchetti S, et al. Glucocorticoid-induced leucine zipper inhibits interferon-gamma production in B cells and suppresses colitis in mice. Front Immunol. (2018) 9:1720. doi: 10.3389/fimmu.2018.01720

121. Cohen N, Mouly E, Hamdi H, Maillot M-C, Pallardy M, Godot V, et al. GILZ expression in human dendritic cells redirects their maturation and prevents antigen-specific T lymphocyte response. Blood. (2006) 107:2037-44. doi: 10.1182/blood-2005-07-2760

122. Hamdi H, Godot V, Maillot M-C, Prejean MV, Cohen N, Krzysiek R, et al. Induction of antigen-specific regulatory $\mathrm{T}$ lymphocytes by human dendritic 
cells expressing the glucocorticoid-induced leucine zipper. Blood. (2007) 110:211-9. doi: 10.1182/blood-2006-10-052506

123. Calmette J, Ellouze M, Tran T, Karaki S, Ronin E, Capel F, et al. Glucocorticoid-induced leucine zipper enhanced expression in dendritic cells is sufficient to drive regulatory $\mathrm{T}$ cells expansion in vivo. J Immunol. (2014) 193:5863-72. doi: 10.4049/jimmunol.1400758

124. Calmette J, Bertrand M, Vétillard M, Ellouze M, Flint S, Nicolas $\mathrm{V}$, et al. Glucocorticoid-induced leucine zipper protein controls macropinocytosis in dendritic cells. J Immunol. (2016) 197:4247-56. doi: 10.4049/jimmunol.1600561

125. Hoppstädter J, Kessler SM, Bruscoli S, Huwer H, Riccardi C, Kiemer AK. Glucocorticoid-induced leucine zipper: a critical factor in macrophage endotoxin tolerance. J Immunol. (2015) 194:6057-67. doi: 10.4049/jimmunol.1403207

126. Hoppstädter J, Diesel B, Linnenberger R, Hachenthal N, Flamini S, Minet M, et al. Amplified host defense by toll-like receptor-mediated downregulation of the glucocorticoid-induced leucine zipper (GILZ) in macrophages. Front Immunol. (2019) 9:3111. doi: 10.3389/fimmu.2018.03111

127. Ricci E, Ronchetti S, Gabrielli E, Pericolini E, Gentili M, Roselletti E, et al. GILZ restrains neutrophil activation by inhibiting the MAPK pathway. $J$ Leukoc Biol. (2019) 105:187-94. doi: 10.1002/JLB.3AB0718-255R

128. Ricci E, Ronchetti S, Pericolini E, Gabrielli E, Cari L, Gentili M, et al. Role of the glucocorticoid-induced leucine zipper gene in dexamethasoneinduced inhibition of mouse neutrophil migration via control of annexin A1 expression. FASEB J. (2017) 31:3054-65. doi: 10.1096/fj.20160 $1315 \mathrm{R}$

129. Espinasse MA, Pepin A, Virault-Rocroy P, Szely N, Chollet-Martin S, Pallardy M, et al. Glucocorticoid-induced leucine zipper is expressed in human neutrophils and promotes apoptosis through Mcl-1 downregulation. J Innate Immun. (2016) 8:81-96. doi: 10.1159/0004 39052

130. Vago JP, Tavares LP, Garcia CC, Lima KM, Perucci LO, Vieira EL, et al. The role and effects of glucocorticoid-induced leucine zipper in the context of inflammation resolution. J Immunol. (2015) 194:4940-50. doi: 10.4049/jimmunol.1401722

131. Hamdi H, Bigorgne A, Naveau S, Balian A, Bouchet-Delbos L, CassardDoulcier AM, et al. Glucocorticoid-induced leucine zipper: a key protein in the sensitization of monocytes to lipopolysaccharide in alcoholic hepatitis. Hepatology. (2007) 46:1986-92. doi: 10.1002/hep.21880

132. Hoppstadter J, Hachenthal N, Valbuena-Perez JV, Lampe S, Astanina $\mathrm{K}$, Kunze $\mathrm{MM}$, et al. Induction of glucocorticoid-induced leucine zipper (GILZ) contributes to anti-inflammatory effects of the natural product curcumin in macrophages. J Biol Chem. (2016) 291:22949-60. doi: 10.1074/jbc.M116.733253

133. Hoppstädter J, Kiemer AK. Glucocorticoid-induced leucine zipper (GILZ) in immuno suppression: master regulator or bystander? Oncotarget. (2015) 6:38446-57. doi: 10.18632 /oncotarget.6197

134. Hoppstadter J, Diesel B, Eifler LK, Schmid T, Brune B, Kiemer AK. Glucocorticoid-induced leucine zipper is downregulated in human alveolar macrophages upon Toll-like receptor activation. Eur J Immunol. (2012) 42:1282-93. doi: 10.1002/eji.201142081

135. Sundahl N, Bridelance J, Libert C, De Bosscher K, Beck IM. Selective glucocorticoid receptor modulation: new directions with non-steroidal scaffolds. Pharmacol Ther. (2015) 152:28-41. doi: 10.1016/j.pharmthera.2015.05.001
136. Fan H, Kao W, Yang YH, Gu R, Harris J, Fingerle-Rowson $\mathrm{G}$, et al. Macrophage migration inhibitory factor inhibits the antiinflammatory effects of glucocorticoids via glucocorticoid-induced leucine zipper. Arthritis Rheum. (2014) 66:2059-70. doi: 10.1002/art. 38689

137. Baschant U, Frappart L, Rauchhaus U, Bruns L, Reichardt HM, Kamradt T, et al. Glucocorticoid therapy of antigen-induced arthritis depends on the dimerized glucocorticoid receptor in T cells. Proc Natl Acad Sci USA. (2011) 108:19317-22. doi: 10.1073/pnas.1105857108

138. Schäcke H, Döcke W-D, Asadullah K. Mechanisms involved in the side effects of glucocorticoids. Pharmacol Ther. (2002) 96:23-43. doi: 10.1016/S0163-7258(02)00297-8

139. Cunnane G, Lane NE. Steroid-induced osteoporosis in systemic lupus erythematosus. Rheum Dis Clin North Am. (2000) 26:311-29, vi-vii. doi: 10.1016/S0889-857X(05)70140-X

140. Shi X, Shi W, Li Q, Song B, Wan M, Bai S, et al. A glucocorticoid-induced leucine-zipper protein, GILZ, inhibits adipogenesis of mesenchymal cells. EMBO Rep. (2003) 4:374-80. doi: 10.1038/sj.embor.embor805

141. Zhang W, Yang N, Shi XM. Regulation of mesenchymal stem cell osteogenic differentiation by glucocorticoid-induced leucine zipper (GILZ). J Biol Chem. (2008) 283:4723-9. doi: 10.1074/jbc.M704147200

142. Pan G, Cao J, Yang N, Ding K, Fan C, Xiong WC, et al. Role of glucocorticoidinduced leucine zipper (GILZ) in bone acquisition. J Biol Chem. (2014) 289:19373-82. doi: 10.1074/jbc.M113.535237

143. Bruscoli S, Donato V, Velardi E, Di Sante M, Migliorati G, Donato $\mathrm{R}$, et al. Glucocorticoid-induced leucine zipper (GILZ) and long GILZ inhibit myogenic differentiation and mediate anti-myogenic effects of glucocorticoids. J Biol Chem. (2010) 285:10385-96. doi: 10.1074/jbc.M109.070136

144. Xiong J, Xu L, Qu WM, Li ZL, Shang ZH, Li YH, et al. Roles of GILZ in protein metabolism of L6 muscle cells exposed to serum from septic rats. Genet Mol Res. (2014) 13:8209-19. doi: 10.4238/2014.October.8.2

145. Cannarile L, Cuzzocrea S, Santucci L, Agostini M, Mazzon E, Esposito E, et al. Glucocorticoid-induced leucine zipper is protective in Th1mediated models of colitis. Gastroenterology. (2009) 136:530-41. doi: 10.1053/j.gastro.2008.09.024

146. Srinivasan M, Janardhanam S. Novel p65 binding glucocorticoidinduced leucine zipper peptide suppresses experimental autoimmune encephalomyelitis. J Biol Chem. (2011) 286:44799-810. doi: 10.1074/jbc.M111.279257

147. Gu R, Ding X, Tang W, Lei B, Jiang C, Xu G. A synthesized glucocorticoidinduced leucine zipper peptide inhibits retinal müller cell gliosis. Front Pharmacol. (2018) 9:331. doi: 10.3389/fphar.2018.00331

Conflict of Interest Statement: The authors declare that the research was conducted in the absence of any commercial or financial relationships that could be construed as a potential conflict of interest.

Copyright (c) 2019 Flynn, Dankers and Morand. This is an open-access article distributed under the terms of the Creative Commons Attribution License (CC BY). The use, distribution or reproduction in other forums is permitted, provided the original author(s) and the copyright owner(s) are credited and that the original publication in this journal is cited, in accordance with accepted academic practice. No use, distribution or reproduction is permitted which does not comply with these terms. 